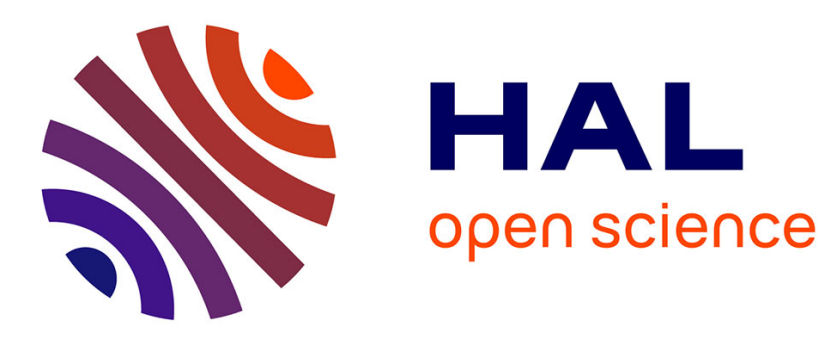

\title{
Cross metathesis of bio-sourced fatty nitriles with acrylonitrile.
}

Johan Bidange, Cédric Fischmeister, Christian Bruneau, Jean-Luc Dubois,

Jean-Luc Couturier

\section{- To cite this version:}

Johan Bidange, Cédric Fischmeister, Christian Bruneau, Jean-Luc Dubois, Jean-Luc Couturier. Cross metathesis of bio-sourced fatty nitriles with acrylonitrile.. Chemical Monthly $=$ Monatshefte für Chemie, 2015, 146 (7), pp.1107-1113. 10.1007/s00706-015-1480-1 . hal-01153405

HAL Id: hal-01153405

https://hal-univ-rennes1.archives-ouvertes.fr/hal-01153405

Submitted on 31 Aug 2015

HAL is a multi-disciplinary open access archive for the deposit and dissemination of scientific research documents, whether they are published or not. The documents may come from teaching and research institutions in France or abroad, or from public or private research centers.
L'archive ouverte pluridisciplinaire HAL, est destinée au dépôt et à la diffusion de documents scientifiques de niveau recherche, publiés ou non, émanant des établissements d'enseignement et de recherche français ou étrangers, des laboratoires publics ou privés. 


\title{
Cross metathesis of bio-sourced fatty nitriles with acrylonitrile
}

\section{Johan Bidange • Cédric Fischmeister • Christian Bruneau• Jean-Luc Dubois • Jean-Luc Couturier}

\section{Dedication}

Dedicated to Franz Stelzer for his important contribution to polymer science.

\begin{abstract}
We report the cross metathesis of two olefinic partners containing different types of nitrile functionality. Thus, cross metathesis of fatty nitriles with acrylonitrile have been achieved with olefin metathesis ruthenium catalysts. 10-Undecenenitrile provides 2-dodecenedinitrile with a high turnover number of 13280 in the green solvent diethyl carbonate. Cross metathesis with the internal carbon-carbon double bond of oleonitrile gave the expected products and the cleavage of the internal double bond proved to be more difficult probably owing to faster catalyst decomposition.
\end{abstract}

Keywords Homogeneous catalysis $\bullet$ Ruthenium catalysis $\bullet \alpha, \omega$-dinitriles

- Renewables • Green chemistry

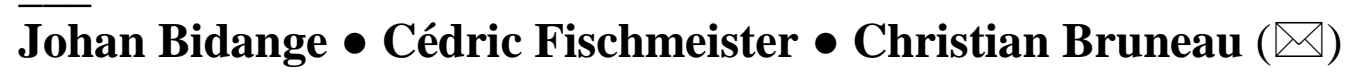

UMR 6226 CNRS - Université de Rennes 1, Institut des Sciences chimiques de Rennes, OMC-Organometallics : Materials and Catalysis, Center for Catalysis and Green Chemistry - Campus de Beaulieu, 35042 Rennes Cedex, France. 
E-mail: christian.bruneau@ univ-rennes1.fr.

Tel: +33 223236283; Fax: +33 223236939

\section{Jean-Luc Dubois}

ARKEMA France, Colombes, France

\section{Jean-Luc Couturier}

ARKEMA France, Pierre-Bénite, France

\section{Introduction}

In the context of sustainable chemistry, the use of renewable and bio-sourced carbon feedstocks has a strong potential to complement and replace petrochemical resources [1-3]. Among natural resources, fats and oils derived from triglycerides have found a place of choice for the access to biofuels [4, 5], polymers, [6-9] and fine chemicals [10-12]. Taking advantage of the reactivity of carbon-carbon double bonds, olefin cross metathesis is especially appropriate to shorten carbon chains by cleavage of unsaturations by ethenolysis [13-18], and to introduce functional groups at the terminal or internal position of unsaturated of fatty acid derivatives. Introduction of ester groups to produce diesters, precursors of polyesters, has been achieved by cross metathesis with acrylates [19-21]. Acrolein has also been used as cross metathesis partner to introduce a reactive aldehyde that can be easily transformed into a fatty alcohol or an amine derivative [22-24]. Functional allylic partners such as allylic halide [25-26] or acetate [27-28] have also been used to introduce a reactive allylic functionality at the end of 
a fatty carbon chain. Another important cross metathesis partner that allows further transformation into amines is acrylonitrile [29]. It has been considered for a long time as a reluctant substrate for cross metathesis and has been applied for fats and oils transformations only when ruthenium catalysts bearing a chelating benzylidene carbene ligand appeared [30, 31]. Thus undec-10-enoic acid and methyl ester [32], undecyl-10-enic aldehyde [22] bearing a terminal double bond, and methyl oleate $[32,33]$ octadec-9enoic diacid and diester [32] as internal olefins reacted efficiently with acrylonitrile in the presence of the second generation Hoveyda catalyst giving access to $\alpha, \omega$-bifunctional products. To our knowledge, cross metathesis of 10-undecenenitrile with methyl acrylate represents a scarce example of metathesis involving an unsaturated bio-sourced fatty nitrile with an electron deficient olefin [34]. We now show that cross metathesis of 10-undecenenitrile and oleonitrile with acrylonitrile can be achieved with Hoveyda type catalysts to give $\alpha, \omega$-dinitriles, precurors of diamine monomers for polyamide preparation, and mononitriles that can be hydrogenated into fatty amines. 


\section{Results and Discussion}

Cross metathesis of 10-undecenenitrile with acrylonitrile

10-Undecenenitrile is a bio-sourced product arising from castor oil. Thermal cleavage of methyl ricinoleate produces methyl 10-undecenoate [35]. Hydrolysis into the corresponding acid followed by ammoxidation provides 10-undecenenitrile [36].

The cross metathesis of the terminal olefin 10-undecenenitrile 2 with acrylonitrile 1 was first investigated (Scheme 1). This reaction produced the unsaturated 2-dodecenedinitrile $\mathbf{3}$ together with ethylene.

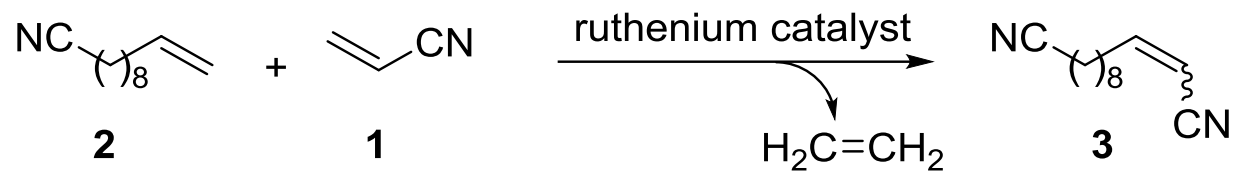

Scheme 1 Cross metathesis of undecenenitrile with acrylonitrile

Based on our knowledge on cross metathesis of fatty acid derivatives with acrylonitrile, the second generation Hoveyda catalyst I was selected to investigate the possibility of achieving this transformation. (Table 1). In toluene as solvent, using $0.5-1 \mathrm{~mol} \%$ of catalyst and 2 equivalents of acrylonitrile, the cross metathesis reaction took place efficiently in short reaction time when the temperature was higher than $80{ }^{\circ} \mathrm{C}$. The reaction was selective as the expected stereoisomers of $\mathbf{3}$ were formed as major products with only trace amounts of undesired products, which were probably 
resulting from cross metathesis of acrylonitrile with 9-undecenenitrile resulting from double bond migration. In particular, no C20 unsaturated dinitrile (9-eicosenedinitrile) resulting from self-metathesis of $\mathbf{2}$ was detected, and self-metathesis of acrylonitrile is not expected to occur as it has been shown to be a difficult reaction [37] and only a low reactivity producing but-2-enedinitrile at high catalyst loading (2-10 mol\%) was reported with a third generation ruthenium(NHC)(benzylidene)(bis(pyridine) $)$ catalyst $(\mathrm{NHC}=($ bis-(2,6-xylyl)imidazolidinylidene $)$ [38]. As always observed with acrylonitrile as cross metathesis partner, the (Z)-dinitrile $\mathbf{3}$ was obtained as the major stereoisomer in variable ratios (from 4.2 to 7.2), and the efficiency of the reaction was improved in diluted conditions (Table 1, entries 2 and 3 ). The negative effect of high concentration of nitrile substrates has already been pointed out with ruthenium catalysts and also very early with rhenium catalysts [39] and was attributed to catalyst poisoning by the nitrile functionality. Increasing the reaction temperature from 80 to $120{ }^{\circ} \mathrm{C}$ allowed achieving higher conversions from 88 to $97 \%$ (entries $3,4,5$ ). 
Table 1 Cross-metathesis of 10-undecenenitrile and acrylonitrile with catalyst $\mathbf{I}^{a}$

\begin{tabular}{lllllll}
\hline entry & $\begin{array}{l}\text { catalyst } \\
\text { loading }(\mathrm{mol} \%)\end{array}$ & $\begin{array}{l}{[\mathbf{2}]} \\
(\mathrm{mol} / \mathrm{L})\end{array}$ & $\begin{array}{l}\text { temp. } \\
\left({ }^{\circ} \mathrm{C}\right)\end{array}$ & $\begin{array}{l}\text { reaction } \\
\text { time }(\mathrm{h})\end{array}$ & $\begin{array}{l}\text { conv. } \\
(\%)\end{array}$ & $\begin{array}{l}\text { yield of } \mathbf{3}(\mathrm{mol} \%) \\
(\mathrm{Z} / \mathrm{E}) \text { ratio }\end{array}$ \\
\hline 1 & 1 & 0.1 & 80 & 3 & 78 & $75(4.8)$ \\
2 & 0.5 & 0.1 & 80 & 3 & 66 & $65(7.2)$ \\
3 & 0.5 & 0.05 & 80 & 3 & 88 & $87(4.2)$ \\
4 & 0.5 & 0.05 & 100 & 4 & 89 & $88(5.1)$ \\
5 & 0.5 & 0.05 & 120 & 5 & 97 & $96(5.5)$ \\
\hline
\end{tabular}

${ }^{a}$ Reaction conditions: 10 -undecenenitrile $2(0.5 \mathrm{mmol})$, acrylonitrile $\mathbf{1}(1 \mathrm{mmol})$, toluene $\left(5 \mathrm{~cm}^{3}\right.$ or $\left.10 \mathrm{~cm}^{3}\right)$, catalyst $\mathbf{I}(0.005$ or $0.0025 \mathrm{mmol})$, conversion of 2 and yield of $\mathbf{3}$ determined by GC using dodecane as internal standard.

Then other ruthenium catalysts were tested with the objective of reaching high turnover numbers (TON) (Scheme 2).<smiles></smiles>

I<smiles></smiles>

IV<smiles></smiles>

II

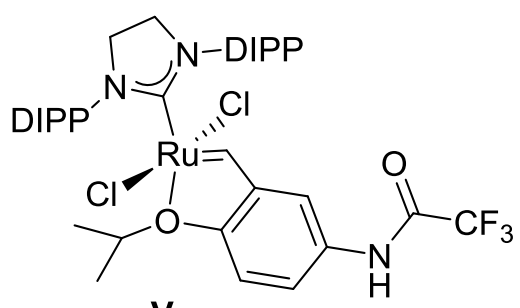

V<smiles>CC(=O)C(C)Oc1ccccc1Cl</smiles>

III<smiles>Cl[R](Cl)(Cl)C1=C(c2ccccc2)c2ccccc21</smiles>

VI<smiles></smiles><smiles></smiles>

Mes: mesityl (2,4,6-trimethylphenyl) DIPP: 2,6-diisopropylphenyl

Scheme 2 Selected ruthenium catalysts 
Hoveyda type catalysts, which have shown their efficiency in cross metathesis with acrylonitrile, and ruthenium indenylidene complexes that are known for their robustness and efficiency in cross metathesis were selected. The best conditions obtained with $\mathbf{I}$ in the initial screening, e. g. $0.5 \mathrm{~mol} \%$ of catalyst in toluene at $120{ }^{\circ} \mathrm{C}$ for $5 \mathrm{~h}$ with a substrate 2 concentration of $0.05 \mathrm{M}$, were applied. As depicted in Table 2, the first generation ruthenium indenylidene catalyst VI was not reactive and the corresponding second generation catalyst VII exhibited poor reactivity. Complex VIII showed interesting catalytic activity (entry 7) but the best catalysts were obviously in the series of chelating benzylidene ruthenium complexes (entries 1, 2, 3,4) leading to TONs of about 180-190. We have already shown that organic dialkyl carbonates were green solvents of choice for olefin metathesis, and again it appeared that the use of diethyl carbonate as solvent with high boiling point $\left(126-128{ }^{\circ} \mathrm{C}\right)$ led to very similar results (entries 1 and 8). Under these conditions of high catalyst loading, it was difficult to select a more active catalyst among I, II, III and IV. 
Table 2 Cross-metathesis of 10-undecenenitrile 2 and acrylonitrile 1: screening of ruthenium catalysts ${ }^{a}$

\begin{tabular}{|l|l|l|l|l|l|}
\hline entry & catalyst & conversion $(\%)$ & yield $(\%)$ & $(Z: E)$ ratio & TON \\
\hline 1 & I & 97 & 84 & 3.0 & 188 \\
\hline 2 & II & 93 & 82 & 2.3 & 186 \\
\hline 3 & III & 91 & 80 & 2.5 & 182 \\
\hline 4 & IV & 91 & 81 & 2.5 & 182 \\
\hline 5 & VI & 0 & - & - & - \\
\hline 6 & VII & 13 & - & 3.5 & 26 \\
\hline 7 & VIII & 83 & 73 & 2.4 & 166 \\
\hline $8^{b}$ & I & 91 & - & 2.8 & 182 \\
\hline
\end{tabular}

${ }^{a}$ Reaction conditions: 10 -undecenenitrile $2(0.5 \mathrm{mmol})$, acrylonitrile $\mathbf{1}(1 \mathrm{mmol})$, toluene $\left(10 \mathrm{~cm}^{3}\right)$, catalyst $\mathbf{I}(0.0025 \mathrm{mmol}, 0.5 \mathrm{~mol} \%), 120{ }^{\circ} \mathrm{C}, 5 \mathrm{~h}$, conversion of 2 determined with dodecane as internal standard. Isolated yields. TON: conversion/catalyst loading.

${ }^{b}$ solvent : DEC

In previous works on cross metathesis of acrylonitrile with fatty acid esters, we have shown a very positive effect on the TONs of the slow addition of the catalyst. This effect was attributed to short lifetime of the catalyst due to fast decomposition at high catalyst concentration. Therefore, the slow addition of a catalyst solution to the reaction mixture was explored by syringe-pump addition over a period of $2.7 \mathrm{~h}$ followed by $2.3 \mathrm{~h}$ reaction time (Table 3). In order to significantly increase the TONs of the reaction, catalysts I, II, III, IV and VIII were chosen to perform the cross metathesis of $\mathbf{1}$ and $\mathbf{2}$ under these conditions with decreasing catalyst loadings at 100 and $120^{\circ} \mathrm{C}$. First, only the catalyst was added dropwise with a seringe pump (entries 1-5), and then the catalyst and 1 equivalent excess of acrylonitrile were added simultaneously via two syringes pumps in order to decrease the duration of their detrimental interaction at high temperature in the reaction mixture. 
Table 3 Cross-metathesis of 10-undecenenitrile 2 and acrylonitrile 1: slow addition of catalyst and acrylonitrile ${ }^{a}$

\begin{tabular}{|l|l|l|l|l|l|l|l|}
\hline entry & $\begin{array}{l}\text { catalyst } \\
(\mathrm{mol} \%)\end{array}$ & solvent & $\begin{array}{l}\text { temp. } \\
\left({ }^{\circ} \mathrm{C}\right)\end{array}$ & $\begin{array}{l}\text { conv. } \\
(\%)\end{array}$ & $\begin{array}{l}\text { yield } \\
(\%)\end{array}$ & $\begin{array}{l}(Z: E) \\
\text { ratio }\end{array}$ & TON \\
\hline 1 & I $(0.05)$ & toluene & 100 & 89 & 80 & 2.7 & 1780 \\
\hline 2 & II $(0.05)$ & toluene & 100 & 92 & 83 & 3.6 & 1840 \\
\hline 3 & III $(0.05)$ & toluene & 100 & 92 & 75 & 3.4 & 1840 \\
\hline 4 & IV $(0.05)$ & toluene & 100 & 85 & 76 & 3.2 & 1700 \\
\hline 5 & VIII $(0.05)$ & toluene & 100 & 87 & 82 & 3.8 & 1740 \\
\hline 6 & I $(0.0125)^{b}$ & toluene & 100 & 67 & 59 & 2.0 & 5360 \\
\hline 7 & II $(0.0125)^{b}$ & toluene & 100 & 76 & 66 & 2.0 & 6080 \\
\hline 8 & III $(0.0125)^{b}$ & toluene & 100 & 74 & 63 & 2.2 & 5920 \\
\hline 9 & IV $(0.0125)^{b}$ & toluene & 100 & 62 & 53 & 2.6 & 4960 \\
\hline 10 & VIII $(0.0125)^{b}$ & toluene & 100 & 51 & 43 & 3.0 & 4080 \\
\hline 11 & I $(0.0125)^{b}$ & DEC & 120 & 84 & 80 & 3.4 & 6720 \\
\hline 12 & II $(0.0125)^{b}$ & DEC & 120 & 93 & 90 & 2.9 & 7440 \\
\hline 13 & III $(0.0125)^{b}$ & DEC & 120 & 91 & 87 & 3.1 & 7280 \\
\hline 14 & IV $(0.0125)^{b}$ & DEC & 120 & 87 & 84 & 3.2 & 6960 \\
\hline 15 & VIII $(0.0125)^{b}$ & DEC & 120 & 60 & 53 & 3.5 & 4800 \\
\hline 16 & I $(0.00625)^{b}$ & DEC & 120 & 76 & 70 & 3.4 & 12160 \\
\hline 17 & II $(0.00625)^{b}$ & DEC & 120 & 80 & 76 & 3.4 & 12800 \\
\hline 18 & III $(0.00625)^{b}$ & DEC & 120 & 76 & 73 & 3.4 & 12160 \\
\hline 19 & IV $(0.00625)^{b}$ & DEC & 120 & 68 & 64 & 3.5 & 10880 \\
\hline 20 & V $(0.00625)^{b}$ & DEC & 120 & 83 & 78 & 3.2 & 13280 \\
\hline 21 & I $(0.00625)^{b}$ & $p$-xylene & 120 & 59 & 52 & 3.1 & 8320 \\
\hline
\end{tabular}

${ }^{a}$ Reaction conditions: 10 -undecenenitrile $2(0.5 \mathrm{mmol})$, acrylonitrile $1(1 \mathrm{mmol})$, solvent $\left(8 \mathrm{~cm}^{3}\right)$, conversion of 2 determined with dodecane as internal standard. Isolated yields. Injection of a catalyst solution $\left(2 \mathrm{~cm}^{3}\right.$ added within $\left.2.7 \mathrm{~h}\right)$ then $2.3 \mathrm{~h}$ prolonged heating. TON: conversion/catalyst loading

${ }^{b}$ Initial introduction of 1 equiv. of acrylonitrile $1(0.5 \mathrm{mmol})$ and injection of the catalyst +1 equiv. of acrylonitrile $\left(2 \mathrm{~cm}^{3}\right.$ added within $\left.2.7 \mathrm{~h}\right)$ then $2.3 \mathrm{~h}$ prolonged heating.

With this technique, at $100{ }^{\circ} \mathrm{C}$ in toluene, the conversions were satisfactory and TONs could be increased to 6000 with catalysts II and III (entries 7, 8). However, it became apparent that when the catalyst loading decreased the activities of catalysts I, IV and VIII were lower than those of II and III. The decrease of conversion induced by lower catalyst loading could be compensated by increasing the reaction temperature. Owing to its higher 
boiling point, diethyl carbonate was preferable to toluene for using the slow addition of catalyst procedure. The higher catalytic efficiency of II was confirmed under low catalyst loading (0.00625 mol\%) and a TON of 12800 was reached (entry 17). Catalyst $\mathbf{V}$ featuring a DIPP-NHC ligand and an isopropoxybenzylidene ligand, was also very efficient (entry 20). It can be noted that the most efficient catalysts II and $\mathbf{V}$ are equipped with isopropoxybenzylidene ligands, which are known to favour fast initiation of the metathesis process. The smaller differences between conversions and isolated yields observed in DEC (entries 11-20) as compared to toluene (entries 1-19) showed that the reaction was cleaner in diethyl carbonate. In addition the beneficial impact of this solvent is also illustrated by the much lower conversion observed in $p$-xylene at $0.00625 \mathrm{~mol} \%$ catalyst loading with catalyst I, which gave only $59 \%$ conversion of $\mathbf{2}$ (entries 16 and 21). Cross metathesis of oleonitrile with acrylonitrile

Oleonitrile is a fatty nitrile that is prepared by ammoniation of oleic acid. Ethenolysis of oleonitrile has been recently reported and the difficulty to reach high turnover numbers with the crude material has been pointed out [40]. Cross metathesis of oleonitrile $\mathbf{4}$ with acrylonitrile $\mathbf{1}$ can potentially produce the four main products 5-8 depending on the relative efficiencies of the primary and secondary metathesis transformations (Scheme 3). 


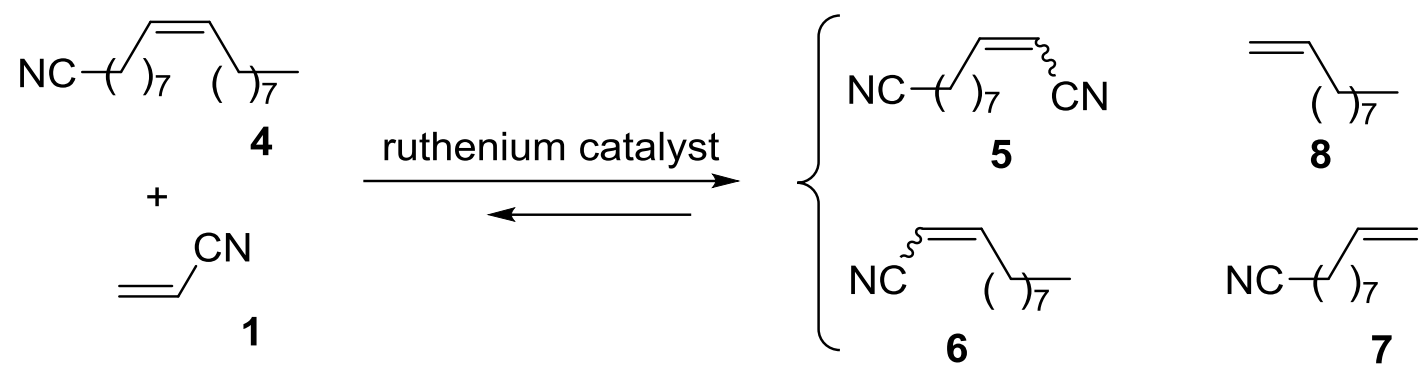

Scheme 3 Cross metathesis of oleonitrile with acrylonitrile

Each pure nitrile-containing product was isolated for quantitative determinations by gas chromatography. Compounds $\mathbf{5}$ and $\mathbf{6}$ were isolated by silica gel chromatography from oleonitrile/acrylonitrile cross metathesis, and 7 from ethenolysis of 4 [40], 1-decene 8 being a commercially available product. To ensure maximum formation of nitrile products, an excess of acrylonitrile was necessary.

We first explored the reaction in diluted solution of toluene $([4]=0.05 \mathrm{M})$ at $100{ }^{\circ} \mathrm{C}$ with high catalyst loading $(0.5 \mathrm{~mol} \%)$ and 4 equivalents of acrylonitrile using directly the slow addition of catalyst technique. Catalysts I, II, III and IV were active and led to $98 \%$ conversion after $4 \mathrm{~h}$, which corresponds to a TON of 196. (Table 4, entries 1-4). No self-metathesis products were detected with this high catalyst loading, but the 4 expected products were formed in various proportions. However, probably due to higher reactivity of terminal olefins with acrylonitrile in secondary cross metathesis processes, the dinitrile $\mathbf{5}$ and mononitrile $\mathbf{6}$ were the major 
products. Similar results were obtained when the catalyst loading was decreased to $0.025 \mathrm{~mol} \%$ and a TON of 3760 with $94 \%$ conversion was obtained with catalyst $\mathbf{V}$. However, products resulting from self-metathesis were produced when the catalyst loading decreased. It was possible to decrease the catalyst loading to $0.0125 \mathrm{~mol} \%$ but the conversion dropped to $56 \%$, which gave a slightly higher TON of 4480 . Attempts to decrease the catalyst loading in diethyl carbonate did not improve the results with these substrates.

Table 4 Cross-metathesis of oleonitrile 4 and acrylonitrile $\mathbf{1}^{a}$

\begin{tabular}{|l|l|l|l|l|}
\hline entry & $\begin{array}{l}\text { catalyst } \\
(\mathrm{mol})\end{array}$ & conversion $(\%)$ & TON & $\begin{array}{l}\text { selectivity } \\
\mathbf{S M} / \mathbf{5} / \mathbf{6} / \mathbf{7} / \mathbf{8}\end{array}$ \\
\hline 1 & I $(0.5)$ & 98 & 196 & \\
\hline 2 & II $(0.5)$ & 98 & 196 & \\
\hline 3 & III $(0.5)$ & 98 & 196 & \\
\hline 4 & IV $(0.5)$ & 97 & 194 & \\
\hline 5 & I $(0.25)$ & 97 & 388 & \\
\hline 6 & II $(0.25)$ & 98 & 392 & $16 / 39 / 35 / 6 / 4$ \\
\hline 7 & III $(0.25)$ & 96 & 384 & $16 / 44 / 34 / 3 / 3$ \\
\hline 8 & IV $(0.25)$ & 96 & 384 & $13 / 36 / 38 / 8 / 5$ \\
\hline 9 & I $(0.025)$ & 86 & 3440 & $15 / 41 / 35 / 5 / 4$ \\
\hline 10 & II $(0.025)$ & 92 & 3680 & $22 / 33 / 29 / 7 / 9$ \\
\hline 11 & III $(0.025)$ & 83 & 3320 & 3760 \\
\hline 12 & V $(0.025)$ & 94 & 4480 & \\
\hline 13 & V $(0.0125)$ & 56 & & \\
\hline
\end{tabular}

${ }^{a}$ Reaction conditions: oleonitrile $4(0.5 \mathrm{mmol})$, acrylonitrile $1(2 \mathrm{mmol})$, toluene $\left(8 \mathrm{~cm}^{3}\right)$, conversion of $\mathbf{4}$ and selectivity were determined by GC using dodecane as internal standard. Injection of a catalyst solution $\left(2 \mathrm{~cm}^{3}\right.$ added within $\left.1 \mathrm{~h}\right)$ then $3 \mathrm{~h}$ prolonged heating. TON: conversion/catalyst loading. SM: self-metathesis product.

\section{Conclusion}

We have shown that cross metathesis of 10 -undecenenitrile with acrylonitrile takes place efficiently with Hoveyda type catalysts at $120{ }^{\circ} \mathrm{C}$ in diethyl 
carbonate as solvent with continuous addition of the catalyst and the excess of acrylonitrile. Under the best conditions, a high turnover number of 13280 at $83 \%$ conversion was obtained with catalyst V. Cross metathesis of acrylonitrile with oleonitrile led to the formation of four main products together with self-metathesis products that appeared at low catalyst loading. Turnover numbers close to 4000 could be obtained with high conversions, but a drop of conversion rapidly occurred when the catalyst loading was decreased below $0.0125 \mathrm{~mol} \%$.

\section{Experimental}

All reactions were carried out using Schlenk tube techniques. Toluene was dried using a MBraun Solvent Purification System. 10-Undecenenitrile and oleonitrile were supplied by Arkema, distilled under vacuum and stored under argon. Acrylonitrile was purchased from Acros Organics and stored under Argon over 4 A MS followed by distillation over $\mathrm{P}_{2} \mathrm{O}_{5}$ prior to use. ${ }^{1} \mathrm{H}$ NMR spectra were recorded at $300 \mathrm{MHz}$ and ${ }^{13} \mathrm{C}$ NMR spectra were recorded at $75.5 \mathrm{MHz}$ on a Bruker $300 \mathrm{WB}$ spectrometer. Reactions were monitored using a Shimadzu 2014 gas chromatograph equipped with Equity TM - 1 Fused Silica capillary column. Pure products were obtained by 
column chromatography on silica gel (Merck Silica Gel 60) using mixtures of petroleum ether and diethyl ether as the eluent.

\section{General procedure for the cross metathesis of 10 -undecenenitrile with}

\section{acrylonitrile in diethylcarbonate (slow addition of catalyst)}

$82 \mathrm{mg}$ of 2 ( $0.5 \mathrm{mmol}, 1$ equiv.) and $26.5 \mathrm{mg}$ of acrylonitrile 1 ( $0.5 \mathrm{mmol}, 1$ equiv.) were dissolved in $8 \mathrm{~cm}^{3}$ of DEC with dodecane as internal standard. The desired amount of catalyst and 1 equiv. of acrylonitrile $(0.5 \mathrm{mmol}, 26.5$ $\mathrm{mg}$ ) were dissolved in $2 \mathrm{~cm}^{3}$ of DEC and added dropwise over a period of 2 h 40 min into the reaction mixture heated at $120^{\circ} \mathrm{C}$. After completion of the addition, the reaction was stirred for 2 h $20 \mathrm{~min}$. After a total reaction time of $5 \mathrm{~h}$, ethyl vinyl ether was added and a sample was collected for GC analysis. After solvent evaporation, the product was purified by column chromatography over silica gel using a mixture of petroleum ether/diethyl ether (9/1) as eluent to furnish $\mathbf{3}$ as a mixture of $E$ and $Z$ isomers.

2-dodecenedinitrile (3, $\left.\mathrm{C}_{12} \mathrm{H}_{18} \mathrm{~N}_{2}, Z: E=4\right):{ }^{1} \mathrm{H} \mathrm{NMR}\left(300 \mathrm{MHz}, \mathrm{CDCl}_{3}\right) \delta=$ 1.34-1.72 (m, 12H, $\left.6 \mathrm{CH}_{2}\right), 2.18-2.47\left(\mathrm{~m}, 4 \mathrm{H}, \mathrm{NCCH}_{2}+\mathrm{CH}_{2} \mathrm{CH}=\mathrm{CHCN}\right)$, 5.30-5.37 (m, 1H, CH=CHCN, Z +E), $6.49\left(\mathrm{dt}, 0.8 \mathrm{H},{ }^{3} J=10.9,7.7 \mathrm{~Hz}\right.$, $\mathrm{C} H=\mathrm{CHCN}, Z), 6.72\left(\mathrm{dt}, 0.2 \mathrm{H},{ }^{3} \mathrm{~J}=16.3,7.0 \mathrm{~Hz}, \mathrm{C} H=\mathrm{CHCN}, E\right) .{ }^{13} \mathrm{C} \mathrm{NMR}$ $\left(75 \mathrm{MHz}, \mathrm{CDCl}_{3}\right) \delta=17.1,25.3,27.6,28.1,28.6,28.8,28.9,29.0,31.8,33.3$, 99.6, 99.8, 116.1, 119.8, 155.1, 156.0. Elemental analysis: calcd: C: 75.74, 
H: 9.53, N: 14.72; Found: C: 75.51, H: 9.46, N: 14.58. HRMS: $[\mathrm{M}+\mathrm{Na}]^{+}$ calcd: 213.13677; found 213.1366

General procedure for the cross metathesis of oleonitrile with acrylonitrile in toluene (slow addition of catalyst)

$132 \mathrm{mg}$ of 4 (0.5 mmol, 1 equiv.) and $106 \mathrm{mg}$ of acrylonitrile 1 (2 mmol, 4 equiv.) were dissolved in $8 \mathrm{~cm}^{3}$ of toluene with dodecane as internal standard. The desired amount of catalyst was dissolved in $2 \mathrm{~cm}^{3}$ of toluene and added dropwise over a period of $1 \mathrm{~h}$ into the reaction mixture heated at $100{ }^{\circ} \mathrm{C}$. After completion of the addition, the reaction was stirred for $3 \mathrm{~h}$. After a total reaction time of $4 \mathrm{~h}$, ethyl vinyl ether was added and a sample was collected for GC analysis. After solvent evaporation, the product was purified by column chromatography over silica gel using a mixture of petroleum ether/diethyl ether (9/1) as eluent to furnish a mixture of products, from which $\mathbf{5}$ and $\mathbf{6}$ could be isolated in pure form.

2-undecenedinitrile (5, $\left.\mathrm{C}_{11} \mathrm{H}_{16} \mathrm{~N}_{2}, Z: E=4\right):{ }^{1} \mathrm{H} \mathrm{NMR}\left(300 \mathrm{MHz}, \mathrm{CDCl}_{3}\right) \delta=$ 1.34-1.73 (m, 10H, $\left.5 \mathrm{CH}_{2}\right), 2.18-2.45\left(\mathrm{~m}, 4 \mathrm{H}, \mathrm{NCCH}_{2}+\mathrm{CH}_{2} \mathrm{CH}=\mathrm{CHCN}\right)$, $5.31\left(\mathrm{~d}, 1 \mathrm{H},{ }^{3} \mathrm{~J}=11.0 \mathrm{~Hz}, \mathrm{CH}=\mathrm{CHCN}, Z+E\right), 6.47(\mathrm{~m}, 0.76 \mathrm{H}, \mathrm{CH}=\mathrm{CHCN}$, Z), $6.70(\mathrm{~m}, 0.24 \mathrm{H}, \mathrm{CH}=\mathrm{CHCN}, E) .{ }^{13} \mathrm{C} \mathrm{NMR}\left(75 \mathrm{MHz}, \mathrm{CDCl}_{3}\right) \delta=17.1$, $25.2,27.4,28.0,28.4,28.6,31.7,33.2,99.6,99.8,116.0,119.8,155.0,155.9$ Elemental analysis: calcd: C: 74.96, H: 9.15, N: 15.89; Found: C: 75.61, H: 8.94, N: 15.35. HRMS: [M+Na] $]^{+}$calcd: 199.12112; found 199.1210 
2-undecenenitrile 6 [41]: ${ }^{1} \mathrm{H} \mathrm{NMR}\left(300 \mathrm{MHz}, \mathrm{CDCl}_{3}\right) \delta=0.89\left(\mathrm{t}, 3 \mathrm{H}, \mathrm{CH}_{3}\right)$, 1.29-1.50 (m, 12H, $6 \mathrm{CH}_{2}$ ), 2.19-2.27 (m, 0.64H, $\left.\mathrm{CH}_{2} \mathrm{CH}=\mathrm{CHCN}, E\right), 2.40-$ $2.47\left(\mathrm{~m}, 1.36 \mathrm{H}, \mathrm{CH}_{2} \mathrm{CH}=\mathrm{CHCN}, Z\right), 5.30-5.36(\mathrm{~m}, 1 \mathrm{H}, \mathrm{CH}=\mathrm{CHCN}, Z+E)$, $6.50\left(\mathrm{dt}, 0.68 \mathrm{H},{ }^{3} \mathrm{~J}=10.8,7.8 \mathrm{~Hz}, \mathrm{CH}=\mathrm{CHCN}, Z\right), 6.73\left(\mathrm{dt}, 0.32 \mathrm{H},{ }^{3} \mathrm{~J}=16.3\right.$, $7.0 \mathrm{~Hz}, \mathrm{CH}=\mathrm{CHCN}, E) .{ }^{13} \mathrm{C} \mathrm{NMR}\left(75 \mathrm{MHz}, \mathrm{CDCl}_{3}\right) \delta=14.1,22.6,27.6$, $28.2,29.0,29.1,29.2,31.8,31.9,33.3,99.4,99.6,116.1,155.3,156.2$ 9-Decenenitrile 7 [40, 42]: ${ }^{1} \mathrm{H}$ NMR $\left(300 \mathrm{MHz}, \mathrm{CDCl}_{3}\right) \delta=1.29-1.65(\mathrm{~m}$, $\left.10 \mathrm{H}, 5 \mathrm{CH}_{2}\right) ; 2.17-2.41\left(\mathrm{~m}, 4 \mathrm{H}, \mathrm{NCCH}_{2}+\mathrm{CH}_{2} \mathrm{CH}=\mathrm{CHCN}\right) ; 4.83-5.07(\mathrm{~m}$, $\left.2 \mathrm{H}, \mathrm{CH}=\mathrm{CH}_{2}\right) ; 5.70-5.84\left(\mathrm{~m}, 1 \mathrm{H}, \mathrm{CH}=\mathrm{CH}_{2}\right) .{ }^{13} \mathrm{C} \mathrm{NMR}\left(75 \mathrm{MHz}, \mathrm{CDCl}_{3}\right)$ $\delta=17.1,25.2,27.5,28.1,28.3,28.3,114.1,115.3,139.2$

\section{Acknowledgements}

The research leading to these results has received funding from the European Union Seventh Framework Programme (FP7/2007-2013) under grant agreement $n^{\circ} 241718$ EuroBioRef. The authors thank Arkema for a fruitful collaboration and for providing 10-undecenenitrile 2 and oleonitrile 4. The authors also thank Umicore Precious Metals Chemistry, Hanau, Germany, for a loan of ruthenium catalysts.

\section{References}

1. Corma A, Iborra S, Velty A, (2007) Chem Rev 107: 2411 
2. Marshall AL, Alaimo PJ (2010) Chem Eur J 16:4970

3. Deuss PJ, Barta K, de Vries JG (2014) Catal Sci Technol 4:2064

4. Alonso DM, Bond JQ, Dumesic JA (2010) Green Chem 12:1493

5. Perego C, Ricci M (2012) Catal Sci Technol 2:1776

6. Montero de Espinosa L, Meier MAR (2011) Eur Polym J 47:837

7. Winkler M, Meier MAR (2014) Green Chem 16:3335

8. Jose J, Pourfallah G, Merkley D, Li S, Bouzidi L, Leao AL, Narine SS (2014) Polym Chem 5:3203

9. Lebarbé T, Maisonneuve L, Nguyen THN, Gadenne B, Alfos C, Cramail H (2012) Polym Chem 3 :2842

10. Montero de Espinosa L, Meier MAR (2012) Top Organomet Chem 39:1

11. Biermann U, Bornscheuer U, Meier MAR, Metzger JO, Schäfer HJ (2011) Angew Chem Int Ed 50:3854

12. Dupé A, Achard M, Fischmeister C, Bruneau, C (2012) ChemSusChem, $5: 2249$

13. Thurier C, Fischmeister C, Bruneau C, Olivier-Bourbigou H, Dixneuf PH (2008) ChemSusChem 1:118

14. Marinescu SC, Levine DS, Zhao Y, Schrock RR, Hoveyda AH (2011) J Am Chem Soc133:10840. 
15. Thomas RM, Keitz BK, Champagne TM, Grubbs RH (2011) J Am Chem Soc 133:7490

16. Marx VM, Sullivan AH, Malaini M, Virgil SC, Keitz BK, Weinberger DS, Bertrand G, Grubbs RH (2015) Angew Chem Int Ed 54:1919

17. Burdett KA, Harris LD, Margl P, Maughon BR, Mokhtar-Zadeh T, Saucier PC, Wasserman EP (2004) Organometallics 23:2027

18. Nickel A, Ung T, Mkrtumyan G, Uy J, Lee CW, Stoianova D, Papazian J, Wei WH, Mallari A, Schrodi Y, Pederson RL (2012) Top Catal $55: 518$

19. Rybak A, Meier MAR (2007) Green Chem 9:1356

20. Biermann U, Meier MAR, Butte W, Metzger JO (2011) Eur J Lipid Sci Technol 113:39

21. Vignon P, Vancompernolle T, Couturier JL, Dubois JL, Mortreux A, Gauvin RM (2014) ChemSusChem Doi: 10.1002/cssc.201403170

22. Miao X, Fischmeister C, Bruneau C, Dixneuf PH (2009) ChemSusChem 2:542

23. Rountree SM, Taylor SFR, Hardacre C, Lagunas MC, Davey PN (2014) Appl Catal 486:94

24. Bonin H, Keraani A, Dubois JL, Brandhorst M, Fischmeister C, Bruneau C (2015) Eur J Lipid Sci Technol 117 :209

25. Jacobs T, Rybak A, Meier MAR (2009) Appl Catal A 353:32 
26. Bilel H, Hamdi N, Zagrouba F, Fischmeister C, Bruneau C (2014) Catal Sci Technol 4:2064

27. Behr A, Gomes JP (2011) Beilstein J Org Chem 7:1

28. Spiccia ND, Border E, Illesinghe J, Jackson WR, Robinson AJ (2013) Synthesis 45:1683

29. Miao X, Fischmeister C, Bruneau C, Dixneuf PH, Dubois JL, Couturier JL (2012) ChemSusChem 5:1410

30. Bruneau C, Fischmeister C, Miao X, Malacea R, Dixneuf PH (2010) Eur J Lipid Sci Technol 112:3

31. Miao X, Dixneuf PH, Fischmeister C, Bruneau C (2011) Green Chem $13: 2258$

32. Malacea R, Fischmeister C, Bruneau C, Dubois JL, Couturier JL, Dixneuf PH (2009) Green Chem 11:152

33. Abel GA, Nguyen KO, Viamajala S, Varanasi S, Yamamoto K (2014) RSC Adv 4:55622

34. Miao X, Fischmeister C, Dixneuf PH, Bruneau C, Dubois JL, Couturier JL (2012) Green Chem 14:2179

35. Van der Steen M, Stevens CV, Eeckhout Y, De Buyck L, Ghelfi F, Roncaglia F (2008) Eur J Lipid Sci Technol 111:846

36. Dubois JL, Gillet JP (2008) WO2008145941A9 
37. Van den Aardweg GCN, Bosma RHA, Mol JC (1983) J Chem Soc Chem Commun 262

38. Bai CX, Zhang WZ, He R, Lu XB, Zhang ZQ (2005) Tetrahedron Lett $46: 7225$

39. Bosma RHA, Van den Aardweg, Mol JC (1985) J organomet Chem 280:115

40. Bidange J, Dubois JL, Couturier JL, Fischmeister C, Bruneau C (2014) Eur J Lipid Sci Technol 116:1583

41. Pradal A, Evano G (2014) Chem Commun 50:11907

42. Shimojo H, Moriyama K, Togo H (2013) Synthesis 45:2155 